\title{
PEMAHAMAN MANAJEMEN PERUSAHAAN TENTANG PERATURAN PERPAJAKAN TERHADAP KEPATUHAN WAJIB PAJAK BADAN DI KOTA BANDAR LAMPUNG
}

(Study Kasus di Kota Bandar Lampung)

\author{
Thontowie Dauli, Universitas Bandar Lampung \\ Andrian Wijaya, Universitas Bandar Lampung \\ Chairul Anwar, Universitas Bandar Lampung
}

\begin{abstract}
Abtract
Bandar Lampung is one of a growing city in the economic field in the province of Lampung. One economic sector to support the development of such companies is corporate taxes. But the company is still a lack of awareness of the importance of understanding the tax laws and regulations, and compliance with corporate taxpayers understand. Yet by understanding the tax laws and compliance with corporate taxpayers, the company will also understand the obligations and rights as a taxpayer.

The problems that the authors point out is how the understanding of the company's management of tax regulations on tax compliance entities in Bandar Lampung.

The method used in this paper is a field of research questionnaires. And methods of analysis in this study is the method of qualitative analysis and quantitative analysis. From the analysis of qualitative and quantitative analysis and discussion, it can be concluded that the understanding of the company's management in the city of Bandar Lampung on tax laws on tax compliance bodies have a positive relationship, in which the Taxpayer Compliance significantly influenced by the understanding of the Corporate Management Tax Regulation.
\end{abstract}

Keywords : Management company, Taxation regulation

\section{LATAR BELAKANG}

Salah satu sektor penerimaan negara adalah pajak. Menurut Siti (2007:1) pajak adalah iuran rakyat kepada kas negara berdasarkan Undang-Undang yang dapat dipaksakan dengan tidak mendapat jasa timbal-balik yang berlangsung dapat ditunjukkan dan yang digunakan untuk membayar pengeluaran umum. Setiap orang, khususnya wajib pajak, pasti akan berurusan dengan pajak. Namun tidak sedikit masyarakat yang masih kurang memahami tentang pajak itu sendiri. Hal ini disebabkan karena masyarakat pada umumnya, seringkali mengalami kesulitan dalam upaya melaporkan serta membayar kewajiban pajaknya. Hambatan lainnya adalah rendahnya tingkat kesadaran masyarakat dalam memenuhi kewajiban perpajakan, administrasi perpajakan, dan kemampuan lembaga perpajakan.

Dalam pelaksanaan pemungutan pajak, administrasi pajak akan menghadapi resiko berupa pajak yang tidak dapat ditarik dari wajib pajak karena wajib pajak tersebut tidak mematuhi ketentuan perpajakan sehingga ada pajak terutang yang tidak dibayar. Resiko inilah yang biasa disebut dengan resiko ketidakpatuhan. Untuk efisiensi dan efektifitas 
operasional, administrasi perpajakan seharusnya dapat mengidentifikasi resiko ini sehingga dapat merumuskan strategi-strategi yang akan digunakan untuk menangkal munculnya resiko ketidakpatuhan.

Agar penerimaan negara dari sektor pajak dapat diperoleh secara maksimal, pemerintah berusaha melakukan reformasi terhadap peraturan perpajakan. Tujuan utama pembaharuan perpajakan nasional adalah untuk lebih menegakkan kemandirian kita dalam membiayai pembangunan nasional dengan jalan lebih mengerahkan lagi segenap kemampuan kita sendiri sebagaimana telah diketahui sistem perpajakan yang berlaku pada UndangUndang perpajakan (Casavera, 2008: 1).

Di dalam Ketentuan Umum dan Tata cara Perpajakan sesuai dengan Undang-Undang No.6 Tahun 1983 yang telah diperbaharui terakhir dengan Undang-Undang No.16 Tahun 2009 Sejalan dengan reformasi perpajakan (tax reform) tahun 1983 yang menghasilkan perubahan yang mendasar pada sistem dan mekanisme pemungutan pajak (dari official assessment system menjadi self assessment system), dalam hal ini wajib pajak lah yang harus aktif dalam melaksanakan kewajiban perpajakan, mulai dari mendaftarkan diri sebagai wajib pajak, menghitung, memperhitungkan, melaporkan, serta membayar pajaknya dengan menggunakan Surat Pemberitahuan (SPT). Perubahan sistem pemungutan pajak dari official assessment system menjadi self assessment system ini merupakan salah satu upaya pemerintah untuk meningkatkan kemandirian dalam pembiayaan pembangunan dari penerimaan dalam negeri yang berasal dari pajak, karena penerimaan migas tidak dapat diandalkan lagi, sementara sumber dana dalam negeri hanya sebagai pelengkap. Pajak sangat berperan penting dalam pembangunan suatu daerah, tidak terkecuali pemerinta daerah provinsi Lampung yang sangat mengutamakan penerimaan pajak dalam menjalankan kegiatan pemerintahan untuk mensejahterakan masyarakatnya. Menururt data dari Kantor Pelayanan Pajak Pratama Tanjung Karang, tingkat wajib pajak dan penerimaan pajak setiap tahunnya berfluktuasi yang digambarkan pada table dibawah ini:

Tabel 1.

Data Jumlah Wajib Pajak Badan dan Penerimaan Pajak Penghasilan Tahun 2007-2011

\begin{tabular}{|c|c|c|c|}
\hline Tahun & Jmlh WP Badan & Penerimaan PPh (Rp) & Realisasi \\
\hline 2007 & 104 & 97.539 .751 .887 & $88 \%$ \\
\hline 2008 & 127 & 126.899 .226 .000 & $90 \%$ \\
\hline 2009 & 139 & 145.216 .923 .264 & $85 \%$ \\
\hline 2010 & 154 & 178.472 .844 .032 & $93 \%$ \\
\hline 2011 & 172 & 193.353 .903 .299 & $87 \%$ \\
\hline
\end{tabular}

Sumber : Kantor Pelayanan Pajak Pratama Tanjung Karang tahun 2012

Berdasarkan tabel diatas diperoleh informasi selama kurun waktu 5 tahun terakhir (2007-2011), jumlah wajib pajak dan penerimaan pajak pertambahan nilai pada Kantor Pelayanan Pajak Pratama Tanjung Karang setiap tahunnya.

Pengertian wajib pajak mengenai prosedur perpajakan diharapkan akan meningkatkan kepatuhan wajib pajak, sehingga wajib pajak dapat mengetahui kapan seharusnya ia mendaftarkan diri untuk memperoleh NPWP. Dengan diperolehnya NPWP maka akan timbul kewajiban-kewajiban lainnya, dimana wajib pajak wajib melaporkan SPT masa dan tahunan, melakukan pembayaran pajak tepat pada waktunya. Apabila wajib pajak dilakukan pemeriksaan sehubungan dengan pelaporan SPT yang telah disampaikannya, maka wajib pajak dapat mengetahui segala hak dan kewajibannya. 


\section{TELAAH LITERATUR DAN PENGEMBANGAN HIPOTENSI}

\subsection{Ketentuan Umum dan Tata Cara Perpajakan}

\section{a. Pengertian Wajib Pajak Badan}

Wajib Pajak adalah orang pribadi atau badan, meliputi pembayar pajak, pemotong pajak, dan pemungut pajak, yang mempunyai hak dan kewajiban perpajakan sesuai dengan ketentuan peraturan perundang-undangan.

Badan adalah sekumpulan orang dan/atau modal yang merupakan kesatuan baik yang melakukan usaha maupun yang tidak melakukan usaha yang meliputi perseroan terbatas, perseroan komanditer, perseroan lainnya, badan usaha milik negara atau badan usaha milik daerah dengan nama dan dalam bentuk apa pun, firma, kongsi, koperasi, dana pensiun, persekutuan, perkumpulan, yayasan, organisasi massa, organisasi sosial politik, atau organisasi lainnya, lembaga dan bentuk badan lainnya termasuk kontrak investasi kolektif dan bentuk usaha tetap.

Pengusaha adalah orang pribadi atau badan dalam bentuk apa pun yang dalam kegiatan usaha atau pekerjaannya menghasilkan barang, mengimpor barang, mengekspor barang, melakukan usaha perdagangan, memanfaatkan barang tidak berwujud dari luar daerah pabean,melakukan usaha jasa, atau memanfaatkan jasa dari luar daerah pabean.

Pengusaha Kena Pajak adalah pengusaha yang melakukan penyerahan Barang Kena Pajak dan/atau penyerahan Jasa Kena Pajak yang dikenai pajak berdasarkan Undang-Undang Pajak Pertambahan Nilai 1984 dan perubahannya.

Pajak yang terutang adalah pajak yang harus dibayar pada suatu saat, dalam Masa Pajak, dalam Tahun Pajak, atau dalam Bagian Tahun Pajak sesuai dengan ketentuan peraturan perundang-undangan perpajakan.

\section{b. Nomor Pokok Wajib Pajak (NPWP)}

Nomor pokok wajib pajak (NPWP) adalah nomor yang diberikan kepada Wajib Pajak (WP) sebagai sarana dalam administrasi perpajakan yang dipergunakan sebagai tanda pengenal diri atau identitas Wajib Pajak dalam melaksanakan hak dan kewajiban perpajakannya.

Semua Wajib Pajak berdasarkan self assessment system wajib mendaftarkan diri pada kantor Direktorat Jenderal Pajak (DJP) yang wilayah kerjanya meliputi tempat tinggal atau tempat kedudukan Wajib Pajak untuk dicatat sebagai Wajib Pajak dan sekaligus mendapatkan NPWP. Selain mendatangi Kantor Pelayanan Pajak (KPP), Wajib Pajak dapat pula mendaftarkan diri secara online melalui e-registration di website Direktorat Jenderal Pajak (DJP) www.pajak.go.id. Selain mendapatkan NPWP, Wajib Pajak dapat dikukuhkan sebagai Pengusaha Kena Pajak (PKP) dan kepadanya akan diberikan Nomor Pengukuhan Pengusaha Kena Pajak (NPPKP).

Sesuai pasal 2 ayat 6, Direktur Jenderal Pajak dapat melakukan penghapusan NPWP apabila :

a. Diajukan pemohonan penghapusan NPWP oleh Wajib Pajak dan/atau ahli warisnya apabila Wajib Pajak sudah tidak memenuhi persyaratan subjektif dan/atau objektif ssuai dengan ketentuan peraturan perundang-undangan perpajakan,

b. Wajib Pajak badan dilikuidasi karena penghentian atau penggabungan usaha,

c. Wajib Pajak bentuk usaha tetap menghentikan kegiatan usahanya di Indonesia, atau 
d. Dianggap perlu oleh Direktur Jenderal Pajak untuk menghapuskan NPWP dari Wajib Pajak yang sudah tidak memenuhi persyaratan subjektif dan/atau objektif sesuai dengan ketentuan peraturan perundang-undangan perpajakan.

Direktur Jenderal Pajak setelah melakukan pemeriksaan harus memberi keputusan atas permohonan penghapusan NPWP dalam jangka waktu 6 bulan untuk Wajib Pajak orang pribadi atau 12 bulan untuk Wajib Pajak badan, sejak tanggal permohonan diterima secara lengkap.

\section{c. Surat Pemberitahuan (SPT)}

Surat Pemberitahuan adalah surat yang oleh Wajib Pajak digunakan untuk melaporkan penghitungan dan/atau pembayaran pajak, objek pajak dan/atau bukan objek pajak, dan/atau harta dan kewajiban sesuai dengan ketentuan peraturan perundang-undangan perpajakan.

Secara garis besar SPT dibedakan menjadi dua, yaitu :

a. SPT-Masa, adalah Surat Pemberitahuan untuk suatu Masa Pajak. Masa Pajak adalah jangka waktu yang menjadi dasar bagi Wajib Pajak untuk menghitung, menyetor, dan melaporkan pajak yang terutang dalam suatu jangka waktu tertentu sebagaimana ditentukan dalam Undang-Undang Perpajakan.

b. SPT-Tahunan, adalah Surat Pemberitahuan untuk suatu Tahun Pajak atau Bagian Tahun Pajak. Tahun Pajak adalah jangka waktu 1 tahun kalender kecuali bila Wajib Pajak menggunakan tahun buku yang tidak sama dengan tahun kalender. Sedangkan Bagian Tahun Pajak adalah bagian dari jangka waktu 1 Tahun Pajak.

Wajib Pajak dapat memperpanjang jangka waktu penyampaian SPT-Tahunan $\mathrm{PPh}$ untuk paling lama 2 bulan dengan cara menyampaikan pemberitahuan secara tertulis atau dengan cara lain kepada Direktur Jenderal Pajak yang ketentuannya diatur dengan atau berdasarkan Peraturan Menteri Keuangan. Pemberitahuan tersebut harus disertai dengan penghitungan sementara pajak yang terutang dalam 1 Tahun Pajak dan Surat Setoran Pajak sebagai bukti pelunasan kekurangan pembayaran pajak yang terutang, yang ketentuannya diatur dengan atau berdasarkan Peraturan Menteri Keuangan.

Sesuai pasal 3 ayat 7, SPT bisa dianggap tidak disampaikan apabila :

1. SPT tidak ditandatangani,

2. SPT tidak sepenuhnya dilampiri keterangan dan/atau dokumen yang diperlukan,

3. SPT yang menyatakan lebih bayar disampaikan setelah 3 tahun sesudah berakhirnya Masa Pajak, Bagian Tahun Pajak atau Tahun Pajak, dan Wajib Pajak telah ditegur secara tertulis, dan SPT disampaikan setelah DJP melakukan pemeriksaan atau menerbitkan Surat Ketetapan Pajak (SKP).

\section{d. Surat Setoran Pajak (SSP) dan Pembayaran Pajak}

Surat Setoran Pajak adalah bukti pembayaran atau penyetoran pajak yang telah dilakukan dengan menggunakan formulir atau telah dilakukan dengan cara lain ke kas negara melalui tempat pembayaran yang ditunjuk oleh Menteri Keuangan. Wajib Pajak dapat mengajukan permohonan secara tertulis untuk mengangsur atau menunda pembayaran pajaknya. Syaratnya yaitu :

1. Permohonan diajukan sebelum jatuh tempo.

2. Menyatakan alasan-alasan penundaan pembayaran.

3. Menyatakan jumlah pajak yang dimohonkan untuk diangsur atau ditunda. 
Direktur Jenderal Pajak atas permohonan Wajib Pajak dapat memberikan persetujuan untuk mengangsur atau menunda pembayaran pajak termasuk kekurangan pembayaran pajak terutang berdasarkan SPT-Tahunan PPh paling lama 12 bulan, yang pelaksanaannya diatur dengan atau berdasarkan Peraturan Menteri Keuangan.

\section{e. Surat Ketetapan Pajak (SKP)}

Surat Ketetapan Pajak adalah surat ketetapan yang meliputi Surat Ketetapan Pajak Kurang Bayar (SKPKB), Surat Ketetapan Pajak Kurang Bayar Tambahan (SKPKBT), Surat Ketetapan Pajak Nihil (SKPN), dan Surat Ketetapan Lebih Bayar (SKPLB).

\section{Surat Ketetapan Pajak Kurang Bayar (SKPKB)}

Surat Ketetapan Pajak Kurang Bayar (SKPKB) adalah surat ketetapan pajak yang menentukan besarnya jumlah pokok pajak, jumlah kredit pajak, jumlah kekurangan pembayaran pokok pajak, besarnya sanksi administrasi, dan jumlah pajak yang masih harus dibayar. Sesuai pasal 13 ayat 1, dalam jangka waktu 5 tahun setelah saat terutangnya pajak atau berakhirnya Masa Pajak, Bagian Tahun Pajak, atau Tahun Pajak, Direktur Jenderal Pajak dapat menerbitkan SKPKB apabila :

1. Berdasarkan hasil pemeriksaan atau keterangan lain pajak yang terutang tidak atau kurang dibayar,

2. SPT tidak disampaikan dalam waktunya dan setelah ditegur secara tertulis tidak juga disampaikan dalam waktu menurut surat teguran,

3. Berdasarkan pemeriksaan mengenai PPN dan PPn BM ternyata tidak seharusnya dikompensasikan selisih lebih pajak atau tidak seharusnya dikenai tarif $0 \%$, atau

4. Kewajiban menyelenggarakan pembukuan atau pencatatan tidak terpenuhi, sehingga tidak dapat diketahui besarnya pajak yang terutang.

Jumlah kekurangan pajak yang terutang dalam SKPKB pada poin 1 ditambah dengan sanksi administrasi berupa bunga sebesar $2 \%$ per bulan paling lama 24 bulan, dihitung sejak saat terutangnya pajak atau berakhirnya Masa Pajak, Bagian Tahun Pajak, atau Tahun Pajak sampai dengan diterbitkannya SKPKB. Jumlah pajak dalam SKPKB pada poin 2, 3, dan 4 ditambah dengan sanksi administrasi berupa kenaikan sebesar :

a. $\quad 50 \%$ dari PPh yang tidak atau kurang dibayar dalam 1 Tahun Pajak

b. $100 \%$ dari PPh yang tidak atau kurang dipotong, tidak atau kurang dipungut, tidak atau kurang disetor, dan dipotong atau dipungut tetapi tidak atau kurang disetor, atau

c. $100 \%$ dari PPN dan PPn BM yang tidak atau kurang dibayar.

\section{Surat Ketetapan Pajak Kurang Bayar Tambahan (SKPKBT)}

Surat Ketetapan Pajak Kurang Bayar Tambahan (SKPKBT) adalah surat ketetapan pajak yang menentukan tambahan atas jumlah pajak yang telah ditetapkan. Sesuai pasal 15 ayat 1 , dalam jangka waktu 5 tahun setelah saat terutangnya pajak atau berakhirnya Masa Pajak, Bagian Tahun Pajak, atau Tahun Pajak, Direktur Jenderal Pajak dapat menerbitkan SKPKBT apabila ditemukannya data baru yang mengakibatkan penambahan jumlah pajak yang terutang setelah dilakukan tindakan pemeriksaan dalam rangka penerbitan SKPKBT. Jumlah kekurangan pajak yang terutang dalam SKPKBT ditambah dengan sanksi administrasi berupa kenaikan $100 \%$ dari jumlah kekurangan pajak tersebut 


\section{Surat Ketetapan Lebih Bayar (SKPLB)}

Surat Ketetapan Lebih Bayar (SKPLB) adalah surat ketetapan pajak yang menentukan jumlah kelebihan pembayaran pajak karena jumlah kredit pajak lebih besar daripada pajak yang terutang atau seharusnya tidak terutang. Tata cara menerbitkan SKPLB, perhitungan dan pengembalian pembayaran pajak :

1. Wajib Pajak mengajukan permohonan secara tertulis kepada DJP,

2. KPP atas nama DJP menerbitkan SKPLB dalam waktu paling lama 12 bulan sejak permohonan diterima,

3. Apabila SKPLB tidak diterbitkan dalam jangka waktu 12 bulan, maka Wajib Pajak memberitahukan kepada DJP bahwa permohonannya (dianggap) dikabulkan,

4. Dalam waktu 1 bulan sejak surat pemberitahuan diterima, DJP menerbitkan SKPLB sesuai dengan permohonan Wajib Pajak. SKPLB ini dikirim kepada Wajib Pajak dengan tembusan kepada KPP yang bersangkutan,

5. Apabila SKPLB terlambat diterbitkan sebagaimana pada poin 4, kepada Wajib Pajak diberikan imbalann bunga sebesar $2 \%$ per bulan dihitung sejak berakhirnya jangka waktu 1 bulan tersebut sampai dengan saat diterbitkannya SKPLB.

\section{Surat Ketetapan Pajak Nihil (SKPN)}

Surat Ketetapan Pajak Nihil (SKPN) adalah surat ketetapan pajak yang menentukan jumlah kredit pajak atau pajak yang terutang dan tidak ada kredit pajak.

\subsection{Pajak Penghasilan}

Yang menjadi objek pajak adalah penghasilan. Penghasilan yaitu setiap tambahan kemampuan ekonomis yang diterima atau diperoleh Wajib Pajak, baik yang berasal dari Indonesia maupun dari luar Indonesia, yang dapat dipakai untuk konsumsi atau menambah kekayaan Wajib Pajak yang bersangkutan, dengan nama dan bentuk apapun (Mardiasmo, 2003 : 109). Penghasilan dapat dikelompokan menjadi :

1) Penghasilan dari pekerjaan dalam hubungan kerja dan pekerjaan bebas.

2) Penghasilan dari usaha atau kegiatan.

3) Penghasilan dari modal atau penggunaan harta.

4) Penghasilan lain-lain, yaitu penghasilan yang tidak dapat diklasifikasikan ke dalam salah satu dari tiga kelompok penghasilan di atas, seperti keuntungan karena pembebasan utang, keuntungan karena selisih kurs mata uang asing, selisih lebih karena penilaian kembali aktiva, dan hadiah undian.

Penghitungan besarnya Penghasilan Kena Pajak dapat dilakukan dengan 2 cara, yaitu :

1. Menggunakan pembukuan

Penghasilan Kena Pajak badan

$=$ Penghasilan Netto

= Penghasilan Bruto - Biaya yang diperkenankan oleh PPh

2. Menggunakan Norma Penghitungan

Penghasilan Kena Pajak badan

= Penghasilan Netto $\mathrm{x}$ Jumlah peredaran usaha 
Sesuai pasal 22 ayat 1, Menteri Keuangan dapat menetapkan :

a. Bendahara pemerintah untuk memungut pajak sehubungan dengan pembayaran atas penyerahan barang.

b. Badan-badan tertentu untuk memungut pajak dari Wajib Pajak yang melakukan kegiatan di bidang impor atau kegiatan usaha di bidang lain.

c. Wajib Pajak badan tertentu untuk memungut pajak dari pembeli atas penjualan barang yang tergolong sangat mewah.

\subsection{Kepatuhan Administratif}

\section{Prosedur Pengisian Form SPT}

Menurut Angga (2009) dalam blognya pelayanan-pajak.blogspot.com, langkahlangkah pengisian SPT-Tahunan Wajib Pajak badan adalah sebagai berikut :

I. Mengumpulkan data

- Kumpulkan data tentang semua penghasilan yang diterima selama tahun yang bersangkutan,

- Kumpulkan semua data atas semua biaya yang telah dikeluarkan selama tahun yang bersangkutan,

- Kumpulkan bukti potong PPh 23 dan PPh Pasal 22 yang diterima/diperoleh,

- Kumpulkan daftar aktiva yang dimiliki s/d 31 Desember,

- Hitung saldo hutang/pinjaman per 31 Desember,

- Siapkan data pengurus dan komisaris lengkap dengan alamat dan NPWPnya.

II. Mengolah data

- Mengidentifikasi apakah penghasilan tersebut merupakan obyek PPh tidak final, obyek PPh final atau bukan merupakan obyek pajak,

- Melakukan pemilahan mana biaya yang boleh dibiayakan di SPT-Tahunan mana yang tidak boleh dikurangkan.

III. Mengisi form pengisian SPT-Tahunan

- Baca buku petunjuk pengisian SPT-Tahunan dengan cemat.

- Input ke dalam e-SPT PPh Tahunan, mulai dari lampiran.

- Isi terlebih dahulu lampiran SPT sebelum mengisi Induk SPT.

- Bila diperlukan dapat dibuat lampiran tambahan.

- Induk SPT beserta lampirannya diisi rangkap dua :

* Satu lembar untuk Kantor Pelayanan Pajak.

* Satu lembar untuk arsip Wajib Pajak.

- Angka-angka rupiah dalam SPT-Tahunan berikut lampirannya dinyatakan dalam rupiah penuh.

- Ditandatangani oleh Wajib Pajak/pengurus atau kuasa.

Apabila diketahui terdapat kesalahan pada SPT, Wajib Pajak dapat melakukan pembetulan SPT atas kemauan sendiri dengan menyampaikan pernyataan tertulis dalam jangka waktu 2 tahun sesudah terutangnya pajak atau berakhirnya Masa Pajak, Bagian Tahun Pajak, atau Tahun Pajak, dengan syarat DJP belum mulai melakukan tindakan pemeriksaan. Dalam hal Wajib Pajak membetulkan sendiri SPT-Tahunan yang mengakibatkan utang pajak menjadi lebih besar, kepadanya dikenai sanksi administrasi berupa bunga sebesar $2 \%$ per bulan atas jumlah pajak yang kurang dibayar, dihitung sejak saat penyampaian SPT berakhir sampai dengan tanggal pembayaran, dan bagian dari bulan dihitung penuh 1 bulan. 


\subsection{Kepatuhan Teknis}

\section{Penghitungan Pajak Terutang}

Untuk dapat menghitung $\mathrm{PPh}$, terlebih dahulu harus diketahui dasar pengenaan pajaknya. Untuk Wajib Pajak dalam negeri dan Bentuk Usaha Tetap (BUT) yang menjadi dasar pengenaan pajak adalah Penghasilan Kena Pajak. Besarnya Penghasilan Kena Pajak untuk Wajib Pajak badan dihitung sebesar penghasilan netto.

\section{Cara Menghitung Pajak :}

\section{PPh Wajib Pajak badan \\ $=$ Penghasilan Kena Pajak $\mathrm{x}$ Tarif Pajak \\ $=$ Penghasilan Netto $\mathrm{x}$ Tarif Pajak}

Tarif pajak yang dimaksud adalah tarif pajak badan sesuai pasal 17 UU PPh yang mana pada tahun 2009 sebesar 28\%, kemudian turun menjadi 25\% pada tahun 2010 . Berdasarkan penjelasan tersebut maka peneliti merumuskan kerangka pemikiran sebagai berikut:

\begin{tabular}{|l|}
\hline $\begin{array}{c}\text { Pemahaman manajemen } \\
\text { perusahaan tentang peraturan } \\
\text { perpajakan }\end{array}$ \\
\hline - Undang-undang perpajakan \& \\
Peraturan perpajakan \\
- Ketentuan Umum Perpajakan \\
\hline
\end{tabular}

Kepatuhan wajib pajak badan

- Kepatuhan administratif

- Kepatuhan teknis

\section{METODOLOGI PENELITIAN}

Jenis penelitian yang digunakan pada penelitian ini adalah kausalitas, dimana kausalitas merupakan prinsip sebab-akibat yang dibangun oleh hubungan antara suatu kejadian (sebab) dan kejadian kedua (akibat atau dampak).

\subsection{Objek Penelitian}

Objek penelitian pada penelitian ini adalah wajib pajak badan perusahaan yang terdapat di Kota Bandar Lampung.

\section{Populasi}

Populasi yang digunakan dalam penelitian ini adalah wajib pajak badan, yakni seluruh wajib pajak badan yang terdaftar pada Kantor Pelayanan Pajak Pratama Tanjung Karang sebanyak 172 perusahaan pada tahun 2011.

\section{Sampel}

Sampel yang digunakan dalam penelitian ini adalah wajib pajak badan, yaitu sebanyak 43wajib pajak badan yang terdaftar pada Kantor Pelayanan Pajak Pratama Tanjung Karang sebagai responden, dengan random sampling sebagai teknik pengambilan sampel. 


\subsection{Pengumpulan Data}

\section{Sumber Data dan Jenis Data}

Sumber data yang digunakan dalam penelitian ini adalah data primer dan data sekunder. Data primer ini diperoleh secara langsung dari obyek penelitian dengan cara kuesioner, observasi, wawancara. Sedangkan data sekunder yaitu data yang sudah diolah yang bersumber dari Kantor Pelayanan Pajak Pranata Tanjung Karang dan lembaga terkait yang mendukung pada penelitian ini.

\section{Operasional Variabel dan Pengukuran Variabel}

Dalam penelitian ini terdapat 2 variabel dengan indikator sebagai berikut :

Variabel Independent (Pemahaman manajemen perusahaan tentang peraturan perpajakan), yaitu :

1. UU Perpajakan dan Peraturan Perpajakan

2. Ketentuan Umum Perpajakan

Variabel Dependent (Kepatuhan wajib pajak badan) memiliki 2 indikator:

1. Kepatuhan administratif

2. Kepatuhan teknis

Indikator dari setiap variabel di atas dijadikan dasar untuk menyusun kriteria yang dijadikan dasar untk menginterprestasikan hasil dari pengolahan daftar pertanyaan dengan rumus : $\quad \mathrm{I}=\frac{\mathrm{NT}-\mathrm{NR}}{\mathrm{K}}$

Berdasarkan hasil perhitungan tersebut didapat hasil sebagai berikut:

$20 \%-35 \% \quad$ Sangat Kurang Memahami

$36 \%-51 \% \quad$ Kurang Memahami

$52 \%-67 \%$ Cukup Memahami

$68 \%-83 \% \quad$ Memahami

$84 \%-100 \%$ Sangat Memahami

\subsection{Metode Analisis Data}

\subsubsection{Analisis Kualitatif}

Masri Singarimbun dan Sofian Efendi $(1987,111)$ mengemukakan bahwa analisis kualitatif merupakan suatu analisis data yang tidak memerlukan pengujian secara matematis, namun hanya bersifat penjelasan berdasarkan pendapat dan interprestasi terhadap data tangapan responden.

\subsubsection{Analisis Kuantitatif}

\section{Uji Validitas dan Reliabilitas}

Uji validitas (uji kesahihan) adalah suatu alat yang digunakan untuk mengukur valid atau tidaknya suatu kuesioner(Ghozali,2001). Kuisioner dikatakan valid, jika ada hubungan antara item pertanyaan dengan total pertanyaan secara keseluruhan dan besarnya nilai $r$ hitung $\geq \mathrm{r}$ tabel. Uji reliabilitas adalah alat uji untuk mengukur kuesioner yang merupakan indicator dari variable (Ghozali, 2001). Pengukuran dilakukan sekali dan reliabilitas dengan uji statistic Cronbach Alpha ( $\alpha$ ) atau Alpha Cronbach. 


\section{HASIL DAN PEMBAHASAN}

\subsection{Regresi Linear Sederhana}

Regresi Liner sederhana adalah lat yang digunakan untuk mengukur pengaruh variabel $\mathrm{X}$ terhadap variabel $\mathrm{Y}$. Dengan rumus sebagai berikut:

Keterangan:

$$
\mathbf{Y}=\mathbf{a}+\mathbf{b X}
$$

$\mathrm{Y} \quad=$ Kepatuhan Wajib Pajak Badan

$\mathrm{X} \quad=$ Pemahaman Manajemen Perusahaan tentang Peraturan Perpajakan

a $\quad=$ Konstanta

$\mathrm{b} \quad=$ Koofesin Regresi

\section{Pengujian Hipotesis}

Untuk menguji hasil penelitian, maka perlu dilakukan uji hipotesis. Dalam penelitian ini pengujian hipotesis dilakukan dengan uji t. Adapun langkah-langkah pengujian adalah sebagai berikut :

Jika $t_{\text {hitung }}>t_{\text {tabel }}$, maka Ha diterima dan Ho ditolak, Jika $t_{\text {hitung }}<t_{\text {tabel }}$, maka Ha ditolak dan Ho diterima,

\section{Koefisien Determinasi}

Koefisien determinasi $\left(\mathrm{R}^{2}\right)$ pada intinya digunakan untuk mengukur seberapa jauh kemampuan variable independen dalam menerangkan variasi variable dependen. Nilai koefisiendeterminasi ditunjukan oleh $R$ Square $\left(\mathrm{R}^{2}\right)$.Nilai $R$ Square dapat naik atau turun apabila satu variable independen ditambahkan ke dalam model.

\subsection{Analisis Kualitatif}

\section{Frekuensi Responden Variabel (X) Pemahaman Manajemen Perusahaan tentang Peraturan Perpajakan}

Berdasarkan perhitungan dengan menggunakan distribusi frekuensi dengan SPS pada variabel $\mathrm{x}$ dengan masing-masing instrumen pertanyaan Didapat hasil interprestasi sebagai berikut:

a. Berdasarkan item pertanyaan tentang Kewajiban menyelenggarakan pembukuan dan menyelenggarakan pencatatan dapat ditarik kesimpulan bahwa rata - rata responden menjawab Setuju.

b. Berdasarkan item pertanyaan tentang Kewajiban wajib pajak mendaftarkan diri untuk mendapatkan NPWP pada Kantor Pelayanan Pajak (KPP) dapat ditarik kesimpulan bahwarata- rata responden menyatakan Sangat Tidak Setuju,

c. Berdasarkan item pertanyaan tentang Kewajiban mengajukan keberatan terhadap $\mathrm{PPh}$ yang dikenakan dapat ditarik kesimpulan bahwa rata- rata responden $41,9 \%$ menyatakan Setuju,

d. Berdasarkan item pertanyaan tentang Hak untuk menerima kembali konpensasi atas kelebihan pembayaran pajak yang telah di setorkandapat ditarik kesimpulan bahwaratarata responden dari 43 responden yang menanggapai menyatakan Setuju.

e. Berdasarkan item pertanyaan tentang Kewajiban menyelenggarakan pembukuan yang digunakan untuk menghitung besarnya Penghasilan Kena Pajak.dapat ditarik kesimpulan bahwa rata- rata menyatakan Setuju 
f. Berdasarkan item pertanyaan tentangFungsi SSP sebagai bukti pembayaran pajak apabila telah disahkan oleh pejabat KPP yang berwenang atau apabila telah mendapatkan validasi.dapat ditarik kesimpulan bahwa rata- rata responden menyatakan Setuju.

g. Berdasarkan item pertanyaan tentang Pengenaan sanksi administrasi apabila pembayaran pajak dilakukan secara mengangsurdapat ditarik kesimpulan bahwa rata -rata responden menyatakan Setuju.

h. Berdasarkan item pertanyaan tentangFungsiNPWP dalam menjaga ketertiban dalam pembayaran pajak dan dalam pengawasan administrasi perpajakandapat ditarik kesimpulan bahwa rata -rata menyatakan Setuju.

i. Berdasarkan item pertanyaan tentangDJP boleh menerbitkan NPWP secara jabatan apabila terdapat Pengusaha Kena Pajak yang tidak mendaftarkan diri untuk memperoleh NPWPdapat ditarik kesimpulan bahwa rata -rataresponden menyatakan Setuju.

j. Berdasarkan item pertanyaan tentangKewajiban mendapatkan NPWP setelah terdaftar sebagai Wajib Pajak sesuai dengan peraturan perundang-undangan dapat ditarik kesimpulan bahwa rata -rata menyatakan Setuju.

k. Berdasarkan item pertanyaan tentangNorma Penghitungan akan sangat membantu WP yang belum mampu menyelenggarakan pembukuan untuk menghitung penghasilan nettonya dapat ditarik kesimpulan bahwa rata - rata menyataka setuju

1. Berdasarkan item pertanyaan tentangPemungutan pajak oleh bendahara pemerintah yang berkenaan dengan pembayaran atas penyerahan barang dimaksudkan untuk meningkatkan peran serta masyarakat dalam pengumpulan dana melalui sistem pembayaran pajakdapat ditarik kesimpulan bahwa rata -rata menyatakan).

\section{Frekuensi Responden Variabel (Y) Pernyataan Pemahaman Manajemen Perusahaan tentang Kepatuhan Wajib Pajak Badan}

Berdasarkan perhitungan dengan menggunakan distribusi frekuensi dengan SPS pada variabel $\mathrm{Y}$ dengan masing-masing instrumen pertanyaan Didapat hasil interprestasi sebagai berikut:

a. Berdasarkan item pertanyaan tentangTujuan perubahan ketiga UU tentang Ketentuan Umum dan Tata Cara Perpajakan adalah untuk lebih memberikan kepastian hukum serta mengantisipasi perkembangan di bidang teknologi informasi dan perkembangan yang terjadi dalam ketentuan-ketentuan material di bidang perpajakandapat ditarik kesimpulan bahwa rata -ratarespondenmenyatakan Setuju

b. Berdasarkan item pertanyaan tentangPerubahan UU PPh tetap berpegang teguh pada prinsip-prinsip perpajakan yang dianut secara universal, yaitu keadilan, kemudahan, efisiensi administrasi, serta peningkatan dan optimalisasi penerimaan negara dengan tetap mempertahankan self assessment systemrata -ratarespondenmenyatakan Setuju

c. Berdasarkan item pertanyaan SPT WP badan harus ditandatangani oleh pengurus atau direksidapat ditarik kesimpulan bahwa rata -ratarespondenmenyatakan Setuju

d. Berdasarkan item pertanyaan SPT dapat ditarik kesimpulan bahwa rata -rata responden menyatakan Setuju

e. Berdasarkan item pertanyaan WP masih diberi kesempatan mengungkap ketidakbenaran pengisian SPT yang telah disampaikan walaupun jangka waktu pembetulan SPT (2 tahun) sudah berakhir, sepanjang DJP belum menerbitkan SKPdapat ditarik kesimpulan bahwa rata -ratarespondenmenyatakan Setuju

f. Berdasarkan item pertanyaan Batas waktu penyampaian SPT-Tahunan PPh WP badan paling lama 4 bulan setelah akhir Tahun Pajak.dapat ditarik kesimpulan bahwa rata ratarespondenmenyatakan Setuju 
g. Berdasarkan item pertanyaan WP yang terlambat menyampaikan SPT-Tahunan dikenakan denda sebesar Rp.100.000,00 dapat ditarik kesimpulan bahwa rata ratarespondenmenyatakan Setuju

h. Berdasarkan item pertanyaanPenghasilan Kena Pajak merupakan dasar penghitungan untuk menentukan $\mathrm{PPh}$ yang terutang. ditarik kesimpulan bahwa rata ratarespondenmenyatakan Setuju

i. Berdasarkan item pertanyaan Pihak manajemen memahami ketentuan umum perpajakan yang mengatur besarnya tarif pajak sesuai dengan undang-undang perpajakan yang berlaku. ditarik kesimpulan bahwa rata -rata responden menyatakan Setuju

j. Berdasarkan item pertanyaan Penghasilan Netto didapat dengan cara penghasilan bruto dikurangi dengan biaya yang diperkenankan oleh UU PPh. ditarik kesimpulan bahwa rata -ratar esponden menyatakan Setuju

k. Berdasarkan item pertanyaan Apabila DJP mendapatkan bukti jumlah pajak yang terutang menurut SPT yang disampaikan oleh WP tidak benar, DJP boleh menetapkan jumlah pajak yang terutang. ditarik kesimpulan bahwa rata -rata responden menyatakan Setuju

1. Berdasarkan item pertanyaan Pihak manajemen akan dikenai sanksi apabila melakukan rekayasa dalam pelaporan keuangan dengan tujuan untuk mengurangi nilai pajak terhutang. ditarik kesimpulan bahwa rata -rata responden menyatakan Setuju

\subsection{Analisis Kuantitatif}

\section{Uji Validitas}

Uji validitas dilakukan dengan menggunakan alat analisis product moment hasil perhitungan validitas dapat dilihat pada Tabel7 berikut ini:

\section{Tabel 7 Hasil Uji Validitas}

\begin{tabular}{|c|c|c|c|}
\hline Pernyataan & Variabel X & Pernyataan & Variabel Y \\
\hline 1 & 0.649 & 1 & 0.423 \\
\hline 2 & 0.524 & 2 & 0.550 \\
\hline 3 & 0.492 & 3 & 0.447 \\
\hline 4 & 0.351 & 4 & 0.404 \\
\hline 5 & 0.550 & 5 & 0.518 \\
\hline 6 & 0.402 & 6 & 0.549 \\
\hline 7 & 0.457 & 7 & 0.444 \\
\hline 8 & 0.787 & 8 & 0.496 \\
\hline 9 & 0.486 & 9 & 0.513 \\
\hline 10 & 0.555 & 10 & 0.393 \\
\hline 11 & 0.479 & 11 & 0.327 \\
\hline 12 & 0.354 & 12 & 0.521 \\
\hline
\end{tabular}

Sumber: Data Lampiran 4 dan 5 Hasil output SPSS. 2013

Berdasarkan hasil perhitungan tersebut masing-masing pernyataan dinyatakan memiliki tingkat validitas yang baik karena nilai $r$-hitung > nilai r-tabel $(0,301)$ pada $\mathrm{n}=43$ dan taraf signifikan $95 \%$, serta tingkat kesalahan $(\sigma=5 \%)$. 


\section{Uji Reliabilitas}

Uji reliabilitas dilakukan untuk mengukur sejauh mana alat ukur dapat dipercaya atau dapat diandalkan.Hasil perhitungan reliabilitas dapat dilihat pada Tabel8dibawah ini:

Tabel 8. Hasil Perhitungan Reliabilitas

\begin{tabular}{|c|c|c|}
\hline Variabel & Tingkat Validitas & Kesimpulan \\
\hline$(\mathrm{X})$ & 0,809 & Reliabel \\
\hline$(\mathrm{Y})$ & 0,803 & Reliabel \\
\hline
\end{tabular}

SumberHasil output SPSS. 2013

Berdasarkan hasil perhitungan dengan menggunakan SPSS, maka pada masingmasing variabel dinyatakan memiliki tingkat reliabilitas yang baik karena nilai $r$ hitung > nilai $\mathrm{r}$-tabel $(0,301)$ pada $\mathrm{n}=43$ dan taraf signifikan 95\%, serta tingkat kesalahan $(\sigma=5 \%)$.

\section{Analisis Regresi Linier Sederhana}

Analisis data secara kuantitatif dilakukan dengan model analisis regresi linier Sederhana. Berikut ini hasil perhitungan regresi linier sederhana dapat dilihat pada Tabel 8 dibawah ini:

\section{Coefficients}

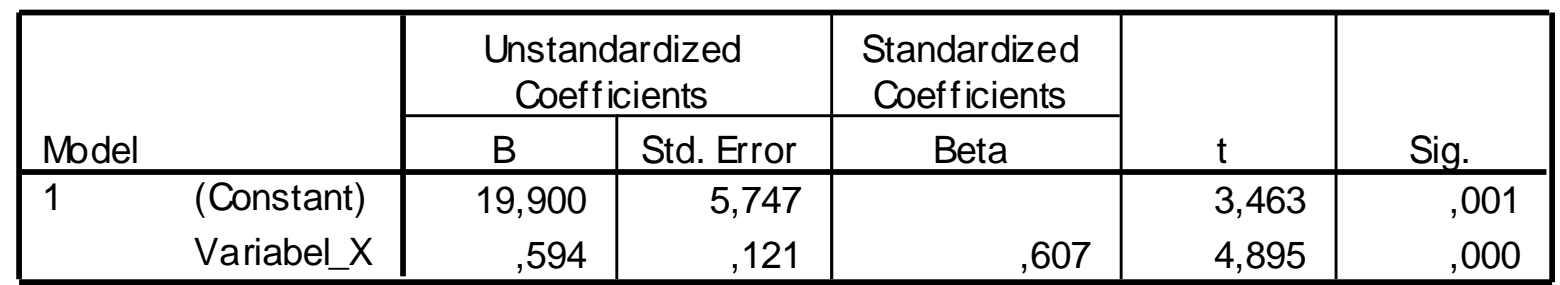

a. Dependent Variable: Variabel_Y

Nilai t hitung untuk variabel bebas (Disiplin Kerja) adalah:

$$
\begin{aligned}
& \mathrm{t} \quad=4,895 \quad \text { Nilai Sig }=0.000 \\
& \mathrm{R}^{2}=0,871 \\
& \mathrm{~F}_{\text {hitung }}=23,964 \\
& \mathbf{Y = 1 9 , 9 0 0 + \mathbf { 0 , 5 9 4 X }}
\end{aligned}
$$

\section{Analisis Korelasi dan Pengaruh}

\section{Antara Variabel X dan Y}

Dari hasil perhitungan dengan menggunakan SPSS didapatkan besarnya korelasi antara variabel (X) dengan variabel (Y) sebesar $\mathbf{0 , 8 7 1 . ~}$

Tabel 9. Pedoman Untuk MemberikanInterprestasi Terhadap Koefisien Korelasi

\begin{tabular}{|c|c|}
\hline Interval Koefisien & Tingkat Hubungan \\
\hline $0,00-0,199$ & Sangat rendah \\
\hline $0,20-0,399$ & Rendah \\
\hline $0,40-0,599$ & Sedang \\
\hline $0,60-0,799$ & Kuat \\
\hline $\mathbf{0 , 8 0}-\mathbf{1 , 0 0 0}$ & Sangat Kuat \\
\hline
\end{tabular}

Sumber: Sugiono ( $2002: 216)$ 
Berdasarkan Tabel 8 di atas, hubungan yang terjadi antara variabel bebas dengan variabel terikat adalah sangat kuat. Untuk menghitung besarnya pengaruh variabel $\mathrm{x}$ terhadap variabel Y menggunakan angka $\mathrm{R}$ Square $\left(\mathrm{R}^{2}\right)$ Koefisien Determinasi dalam perhitungan di atas sebesar $\mathbf{0 , 8 6 9}$ atau sama dengan 86,90\%. Angka tersebut mempunyai arti bahwa sebesar $\mathbf{8 6 , 9 0 \%}$. Variabilitas $\mathrm{Y}$ yang terjadi dapat dijelaskan dengan menggunakan variabel $\mathrm{Y} \%$. Adapun sisanya yaitu 13,1\% merupakan pengaruh variabel bebas lain yang dianggap tetap atau yang tidak diidentifikasi dalam penelitian ini.

\section{Pengujian Hipotesis Statistik}

ANOV A

\begin{tabular}{|c|c|c|c|c|c|c|}
\hline \multicolumn{2}{|c|}{ Model } & $\begin{array}{c}\text { Sum of } \\
\text { Squares }\end{array}$ & $\mathrm{df}$ & Mean Square & $\mathrm{F}$ & Sig. \\
\hline \multirow[t]{3}{*}{1} & Regression & 416,530 & $\overline{1}$ & 416,530 & 23,964 &, $000^{a}$ \\
\hline & Residual & 712,632 & 41 & 17,381 & & \\
\hline & Total & 1129,163 & 42 & & & \\
\hline
\end{tabular}

a. Predictors: (Constant), Variabel_X

b. Dependent Variable: Variabel_Y

\section{Uji Signifikan Nilai F hitung}

$\begin{array}{ll}\mathrm{F}_{\text {hitung }} & =\mathbf{2 3 , 9 6 4} \\ \mathrm{F}_{\text {tabel }} 0,05(1: 43) & =\mathbf{4 , 0 7} \\ \text { Nilai signifikan } & =\mathbf{0 , 0 0 0}\end{array}$

Karena $F_{\text {hitung }}\left(\mathbf{2 3 , 9 6 4 )}>\mathrm{F}_{\text {tabel }}(\mathbf{4 , 0 7})\right.$

maka $\mathrm{H}_{0}$ ditolak dan $\mathrm{H}_{1}$ diterima.

Angka tersebut menunjukkan bahwa secara statistik Kepatuhan Wajib Pajak Badan (Y) dipengaruhi secara nyata dan signifikan $(\mathbf{p} \mathbf{0 , 0 0 0}<\mathbf{0 , 0 5})$ oleh Pemahaman Manajemen Perusahaan tentang Peraturan Perpajakan (X).

\section{Uji Signifikan Nilai t hitung:}

Berdasarkan hasil SPSS, ternyata

didapat nilai:

$\mathrm{t}_{\text {hitung }}=\mathbf{4 , 8 9 5}$ Nilai Signifikan 0,000

$\mathrm{t}_{\text {tabel }}=\mathbf{1 . 6 8 4}$

Ternyata $t_{\text {hitung }}=\mathbf{4 , 8 9 5}>t_{\text {tabel }}=\mathbf{1 , 6 8 4}$, maka $\mathrm{H}_{0}$ ditolak dan Ha diterima

pada tingkat kepercayaan $95 \%$.

\section{KESIMPULAN DAN SARAN}

\subsection{Kesimpulan}

Berdasarkan hasil pembahasan masalah pemahaman Manajemen Perusahaan tentang Peraturan Perpajakan (X) terhadap kepatuhan Wajib Pajak Badan (Y) di Kota Bandar Lampung Lampung secara kuantitatif dan kualitatif, maka dapat ditarik beberapa kesimpulan sebagai berikut:

1. Hasil perhitungan dengan menggunakan analisis regresi linier berganda, besarnya korelasi antaravariabel Pemahaman Manajemen Perusahaan tentang Peraturan Perpajakan (X), 
dengan variabel terikat yaitu Kepatuhan Wajib Pajak Badan (Y)menunjukkan korelasi positif dimana bahwa hubungan antara variabel Pemahaman Manajemen Perusahaan tentang Peraturan Perpajakan (X), dengan variabel terikat yaitu Kepatuhan Wajib Pajak Badan (Y) adalah searah. Artinya, jika Pemahaman Manajemen Perusahaan tentang Peraturan Perpajakan (X) meningkat, maka akan berdampak terhadap meningkatnya Kepatuhan Wajib Pajak Badan (Y).

2. Pengujian keberartian pengaruh variabel bebas secara keseluruhan terhadap variabel terikat digunakan Uji Fisher (Uji F) menunjukkan bahwa secara statistik Kepatuhan Wajib Pajak Badan (Y) dipengaruhi secara nyata dan signifikan oleh Pemahaman Manajemen Perusahaan tentang Peraturan Perpajakan (X).

Untuk melihat besarnya pengaruh variabel Pemahaman Manajemen Perusahaan tentang Peraturan Perpajakan (X), terhadap Kepatuhan Wajib Pajak Badan (Y) secara sendirisendiri atau parsial,menunjukkan ada pengaruh positif Pemahaman Manajemen Perusahaan tentang Peraturan Perpajakan terhadap Pemahaman Manajemen Perusahaan tentang Kepatuhan Wajib Pajak Badan. Ini berarti dapat dinyatakan bahwa, secara statitistik variabel bebas Disiplin Kerja (X) mempengaruhi naik turunnya Kepatuhan Wajib Pajak Badan (Y) di Kota Bandar Lampung

\subsection{Saran}

Berdasarkan kesimpulan di atas maka penulis memberikan saran sebagai berikut:

1. hendaknya melakukan analisis yang lebih mendalam sebelum melakukan penelitian.

2. Manajemen perusahaan hendaknya lebih memperdalam tiap butir pasal yang ada pada peraturan perpajakan yang berlaku saat ini agar dapat meningkatkan kesadaran akan kewajiban dan haknya sebagai wajib pajak dalam rangka mendukung pembangunan nasional di berbagai bidang. dengan cara sering mengikuti seminar-seminar tentang perpajakans yang diselenggarakan oleh kantor pajak dan harus mengikuti perkembangan terbaru dari peraturan perpajakan agar pihak manajemen dapat memahaminya dengan baik.

3. Apabila pembuat kebijakan peraturan perpajakan melakukan perubahan terhadap peraturan perpajakan hendaknya pembuat kebijakan peraturan perpajakan mengkomunikasikan kepada wajib pajak agar tidak terjadi kekeliruan dalam pelaksanaan.

\section{DAFTAR PUSTAKA}

Arikunto, suharsimi. 2001. Manajemen Penelitian, Edisi Baru. Penerbit PT.Rineka Cipta. Jakarta.

Casavera. 2008, Seri Perpajakan Indonesia. Penerbit Graha Ilmu. Jakarta.

Kuncoro, Mudrajat. 2003. Metode Riset untuk Ekonomi Bisnis. Penerbit Erlangga. Jakarta.

Mardiasmo, Prof., Dr., MBA., Ak. 2003. Perpajakan. Andi. Yogyakarta.

Mustikasari, Elia. 2007. Kajian Empiris tentang Kepatuhan Wajib Pajak Badan di Perusahaan Industri Pengolahan di Surabaya. Surabaya.

Nurmantu, Safri. 2005. Pengantar Perpajakan. Granit. Jakarta. 
Santoso, Wahyu. 2006. Analisis Risiko Ketidakpatuhan Wajib Pajak Sebagai Dasar Peningkatan Kepatuhan Wajib Pajak. Bandung.

Sanusi, Anwar. 2012, Metode Penelitian Bisnis. Salemba Empat. Jakarta.

Singarimbun, M. Dan E. Sofyan. 1987. Metode Penelitian Survei. Penerbit LP3ES. Jakarta.

Sugiyono.2003, Metode Penelitian Bisnis. PenerbitAlfabeta. Bandung.

UU Republik Indonesia nomor 28 tahun 2007 tentang Ketentuan Umum dan Tata Cara Perpajakan.

. UU Republik Indonesia nomor 36 tahun 2008 tentang Pajak Penghasilan.

Waluyo. 2011, Perpajakan Indonesia, Edisi 10. Penerbit Salemba Empat. Jakarta.

www.pelayanan-pajak.blogspot.com

www.pajak.go.id

www.google.com 